\title{
A teljes ischaemiás idő prognosztikus jelentősége az ST-elevációval járó szívinfarktus miatt kezelt betegekben
}

\author{
Jánosi András dr. ${ }^{1}$ - Erdős Gergely dr. ${ }^{2}$ - Pach Ferenc Péter dr. ${ }^{2}$ \\ Forster Tamás $d r .^{3}$. Ungi Imre dr. ${ }^{3}$. Ofner Péter $d r .^{1}$ - Andréka Péter dr. ${ }^{1}$

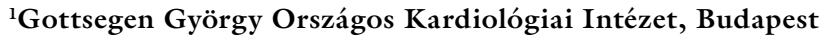 \\ ${ }^{2}$ Felsőbbfokú Tanulmányok Intézete, Kőszeg \\ ${ }^{3}$ Szegedi Tudományegyetem, Általános Orvostudományi Kar, Szent-Györgyi Albert Klinikai Központ, \\ II. Belgyógyászati Klinika, Kardiológiai Központ, Szeged
}

Bevezetés: Az ST-elevációval járó szívinfarktusban (STEMI) a panasz kezdetétől az ér megnyitásáig eltelt idő (teljes ischaemiás idő = TIT) jelentősége a szívizommentés tekintetében jól ismert.

Célkitüzés: A magyarországi, ST-elevációval járó szívinfarktusos betegeknél a TIT meghatározása és prognosztikus jelentőségének vizsgálata Magyarországon.

Módszer: A szívinfarktusos betegek klinikai paramétereit, ellátásuk adatait az ellátók 2014. január 1-je óta kötelező jelleggel rögzítik a Nemzeti Szívinfarktus Regiszter rendszerében. 2014. január 1. és 2016. március 31. között 27157 beteg 28408 infarktusos eseményének adata került rögzítésre. Vizsgálatunkban 7146, STEMI miatt kezelt beteg szerepelt, akiknél a panasz kezdetétől számított 24 órán belül percutan coronariaintervenció (PCI) történt, és ismertek voltak a részidők.

Eredmények: Az utánkövetés átlaga $740 \pm 346$ nap volt. A TIT mediánja 260 perc, ezen belül a leghosszabbnak a prehospitális időt találtuk (medián 205 perc). A TIT befolyásolta a túlélést: amennyiben ez az idő 400 percnél rövidebb volt, akkor a 30 napos, illetve az 1 éves halálozás 7,5\%, illetve 12,2\% volt. Az ennél hosszabb idő esetén 9,2\%, illetve 19,7\% halálozási értékeket találtunk. A többváltozós elemzéskor rövid (<30 nap), közép- (30-364 nap) és hosszú távú ( $\geq 365$ nap) túlélést vizsgáltunk. A diabetes a rövid, míg a kóros kreatininérték, a súlyos koszorúérstatus a rövid és a középtávú túlélést befolyásolta. A PCI a közép- és a hosszú távú túlélés szempontjából volt jelentős. A megelőző myocardialis infarctus és a TIT a hosszú távú túlélést befolyásolta szignifikáns mértékben.

Következtetések: A TIT Magyarországon hosszú, az időveszteség döntő része a prehospitális időszakra esik. A TIT önálló prognosztikai tényező, az időveszteség csökkentése javíthatja a betegek késői életkilátásait.

Orv Hetil. 2018; 159(27): 1113-1120.

Kulcsszavak: ST-elevációval járó szívinfarktus, teljes ischaemiás idő, halálozás, szívinfarktus-regiszter

\section{Prognostic significance of the total ischemic time in patients with ST-elevation myocardial infarction}

Introduction: The significance of the total ischemic time (from the beginning of the complaint to the opening of the vessel) is an important factor for myocardial salvage.

Aim: The aim of the study was to determine the prognostic significance of the TIT in patients with ST elevation myocardial infarction in Hungary.

Method: From 1 January 2014 all patients with myocardial infarction were recorded by law in an on-line database of the Hungarian Myocardial Infarction Registry. Between 1 January 2014 and 31 March 2016, 27157 patients with 28408 myocardial infarction events were recorded. To investigate TIT, 7146 STEMI patients were selected who were treated with percutaneous coronary intervention (PCI) within 24 hours of the beginning of the complaint and all of its components were known.

Results: Average follow-up was $740 \pm 346$ days. The median time of the TIT is 260 minutes, within which the earliest prehospital time was found (median 205 minutes). The TIT influenced survival: if this time was less than 400 minutes, the 30 -day and the 1 -year deaths were $7.5 \%$ and $12.2 \%$, respectively. In longer TIT, higher mortality rate was found $(9.2 \%$ versus $19.7 \%$, respectively). Multivariate analysis was performed for short (<30 days), medium 
(30-364 days) and long-term ( $\geq 365$ days) survival. Diabetes mellitus is a short-term prognostic factor, abnormal creatinine, and severe coronary status have affected short and medium survival. PCI was significant in terms of medium and long-term survival. Previous myocardial infarction and TIT influenced the long-term survival significantly. Conclusions: In Hungary, TIT is too long, and its dominant part falls within the prehospital period. The TIT is an independent prognostic factor, so reducing this time can improve the long-term prognosis of patients with ST-elevation myocardial infarction.

Keywords: ST-elevation myocardial infarction, total ischaemic time, mortality, myocardial infarction registry

Jánosi A, Erdős G, Pach FP, Forster T, Ungi I, Ofner P, Andréka P. [Prognostic significance of the total ischemic time in patients with ST-elevation myocardial infarction]. Orv Hetil. 2018; 159(27): 1113-1120.

(Beéérkezett: 2018. február 27.; elfogadva: 2018. március 12.)

\section{Rövidítések}

$\mathrm{CI}=$ konfidenciaintervallum; Cox $\mathrm{PH}=($ Cox proportion-hazard model) Cox-féle arányos kockázati modell; $\mathrm{HR}=$ (hazard ratio) kockázati arány; NEAK = Nemzeti Egészségbiztosítási Alapkezelö; NSZR = Nemzeti Szívinfarktus Regiszter; PCI = percutan coronariaintervenció; STEMI = (ST-elevation myocardial infarction) ST-elevációval járó szívinfarktus; tajszám = társadalombiztosítási azonosító jel; TIT $=($ total ischemic time $)$ teljes ischaemiás idő

Magyarország mind az egészségi, mind a halálozási mutatókban elmarad a hasonló fejlettségű országoktól. Különösen a rosszindulatú daganatok és a keringési megbetegedések halálozási mutatói tekintetében tartozik hazánk a sereghajtók közé. A kedvezőtlen helyzet okainak megismerése és a szükséges változtatások érdekében - kormányhatározat alapján - a Felsóbbfokú Tanulmányok Intézete megkezdte a „Kiemelt halálozási kockázatú betegségek megelőzésének és ellátásának Big Data elemzése" címü projektjét. A program egyik előzménye, hogy nemzetközi tapasztalatok igazolták, hogy a populációs egészségmenedzsmentre jellemző integrált erőforrás-felhasználás megvalósítható, és eredményességét számos országban igazolták.

A szívinfarktus reperfúziós kezelése - a thrombolysis, illetve a katéteres érmegnyitás - lényegesen javította a betegek prognózisát. A Nemzeti Szívinfarktus Regiszter (NSZR) korábban publikált adatai igazolták, hogy a magyar betegek jelentős hányadánál megtörténik az invazív kezelés, ugyanakkor a betegek 30 napos halálozása magasabb, mint ami a legfejlettebb ellátású országokban megfigyelhető. A beavatkozás hatékonysága azonban nagymértékben függ a revascularisatio idejétől. A legnagyobb arányú szívizommentés az első órákban alkalmazott kezeléstől várható. A revascularisatióig eltelt idő prognosztikus jelentősége évtizedek óta ismert, amit állatkísérletes adatok [1], a thrombolysis [2], illetve a percutan intervenció eredményességét vizsgáló tanulmányok igazoltak $[3,4]$. Amennyiben a beavatkozás nem időben történik, meredeken csökken a maradék múködőképes szívizom mennyisége. Hazai adat csak arra vo- natkozóan van, hogy az ST-elevációval járó szívinfarktus esetén csak a betegek kis hányadánál történik meg a revascularisatio a panasz kezdetétól számított 2 órán belül, olyan időben, amikor a lehető legnagyobb mértékű szívizommentés lenne megvalósítható. Jelen vizsgálatunkban arra kerestünk választ, hogy a hazai infarktusellátás teljességét lefedő Nemzeti Szívinfarktus Regiszter adatbázisában milyen hosszú a panasz kezdetétől az ér megnyitásáig eltelt idő, a késlekedés az ellátás melyik fázisában jelentkezik, illetve az ér megnyitásáig eltelt időnek milyen jelentősége van az ST-elevációval járó szívinfarktusos betegek prognózisának meghatározásában.

\section{Betegek és módszer}

A Nemzeti Szívinfarktus Regiszter (NSZR) a szívinfarktusos betegek ellátásának adatait rögzítő online rendszer, amely minőségbiztosítási elemzést tesz lehetővé. A programban való részvétel - 2014. január 1-je óta - minden egészségügyi szolgáltató számára kötelező. Az NSZR rögzíti a betegek kórelőzményét, a prehospitális időszak eseményeit, a kórházi kezelés adatait, valamint az infarktust követő 1 év alatt bekövetkező adverz történéseket (bármely okból bekövetkező haláleset, újabb myocardialis infarctus, percutan coronariaintervenció [PCI], stroke). Az utánkövetési idő alatt bekövetkező haláleseteket a Nemzeti Egészségbiztosítási Alapkezelő (NEAK) adatai alapján állapítottuk meg, a betegek egészségügyi azonosítójának (tajszám) felhasználásával. Az NSZR múködésével kapcsolatos módszertani kérdéseket korábbi közleményünk tartalmazza [5]. Az NSZR nyilvántartásában 2014. január 1. és 2016. március 31. között 27157 beteg 28408 infarktusos eseményével kapcsolatos 33804 kezelés adatait rögzítettük. A kórházi kezeléseket 30 napig egy eseményhez tartozónak tekintettük. Elemzésünkbe azokat az ST-elevációval járó infarktusos eseményeket vontuk be, amelyeknél az akut szak kórházi kezelése idején - a panaszok kezdetétôl számított 24 órán belül - PCI történt. Ezen feltételnek 10045 beteg 10138 eseménye felelt meg. Elemeztük a teljes ischaemiás időt (total ischemic time $=$ TIT), amelyen a pana- 
szok kezdetétôl az ér megnyitásáig eltelt időt értjük [6, 7]. A TIT vizsgálatához szükséges volt, hogy a releváns adatok (panasz kezdete, kórházba érkezés, az invazív laboratóriumba érkezés, az ér megnyitásának ideje) hiánytalanul rendelkezésre álljanak. Amennyiben egy betegnek több infarktusa volt, akkor csak az elsó esemény adatait elemeztük. Vizsgálatunkban - a fenti szempontok figyelembevétele miatt -7146 beteg ugyanennyi eseményét elemeztük, 2899 beteg eseményét hiányzó adat miatt a vizsgálatból kizártuk. A vizsgált betegcsoport kialakításának részleteit az 1. ábrán szemléltetjük. Annak érdekében, hogy az egész betegcsoportról képet alkothassunk, a vizsgálatból kizárt betegek alapvető klinikai jellemzőit és halálozási adatait ugyancsak feldolgoztuk. Az adatok feldolgozásához az R statisztikai programcsomagot használtuk (verzió 3.4.0). A leíró statisztikai jellemzésben a kategóriaváltozók eloszlásait a gyakoriság (illetve az első kategóriára az arányérték) formájában adtuk meg, a folytonos változók esetében átlag (szórás) formájában adtuk meg a jellemzést. A vizsgálatba bevont versus kizárt betegek közötti különbségek próbastatisztikáihoz a folytonos változóknál Wilcoxon-próbát, a kategóriaváltozóknál pedig khi-négyzet-próbát alkalmaztunk. A túlélési elemzésben a kórházi felvétel dátumától a halálozásig, illetve a megfigyelés végéig (2017. 06. 30.) eltelt idő napokban kiszámított értékét használtuk fel (követési idő). Elsőként a TIT különböző kategóriaszintú felosztásának (binning) Kaplan-Meier-diagram-alapú vizsgálatát végeztük el. A kategóriaképzéshez az ellátási idők eloszlásait vizsgáltuk hisztogram alapján. Megnéztük, hogy milyen TIT-kategóriafelosztások esetén van szignifikáns különbség az egyes ellátásiidő-kategóriák túlélési valószínúségei között [6]. Megállapítottuk, hogy 200 perces felosztásokkal célszerú a TIT kategóriaváltozóját leképezni, mert ekkor az egyes TIT-csoportokban hasonló esetszámok mellett szignifikáns különbség mutatható ki a túlélések között. A TIT alapján három betegcsoportot különítettünk el: <200 perc alatt, 200-399 perc között, $\geq 400$ perc. Vizsgáltuk a TIT-en kívül egyéb tényezők (életkor, nem, kórelőzmény, társbetegségek) hatását a túlélésre egy úgynevezett Cox 'proportion-hazard' $(\mathrm{PH})$ egyváltozós regressziós modell segítségével. Az egyváltozós modellezés során szignifikánsnak bizonyult jellemzőket felhasználva készítettünk egy többváltozós Cox PH regressziós modellt, ahol azt vizsgáltuk meg, hogy együttesen milyen hatással vannak az egyes jellemző́k a túlélésre. A túlélés vizsgálatakor minden egyes változóra meghatároztuk, hogy milyen jelentőséggel bírnak a rövid (<30 nap), a közép- (30-364 nap) és a hosszú távú ( $\geq 365$ nap) halálozás tekintetében.

\section{Eredmények}

\section{A vizsgált betegcsoport jellemzése}

Az elemzésben szereplő és a feldolgozásból kizárt betegek fontosabb adatait az 1. táblázat tartalmazza. A két betegcsoport összehasonlításakor azt találtuk, hogy a

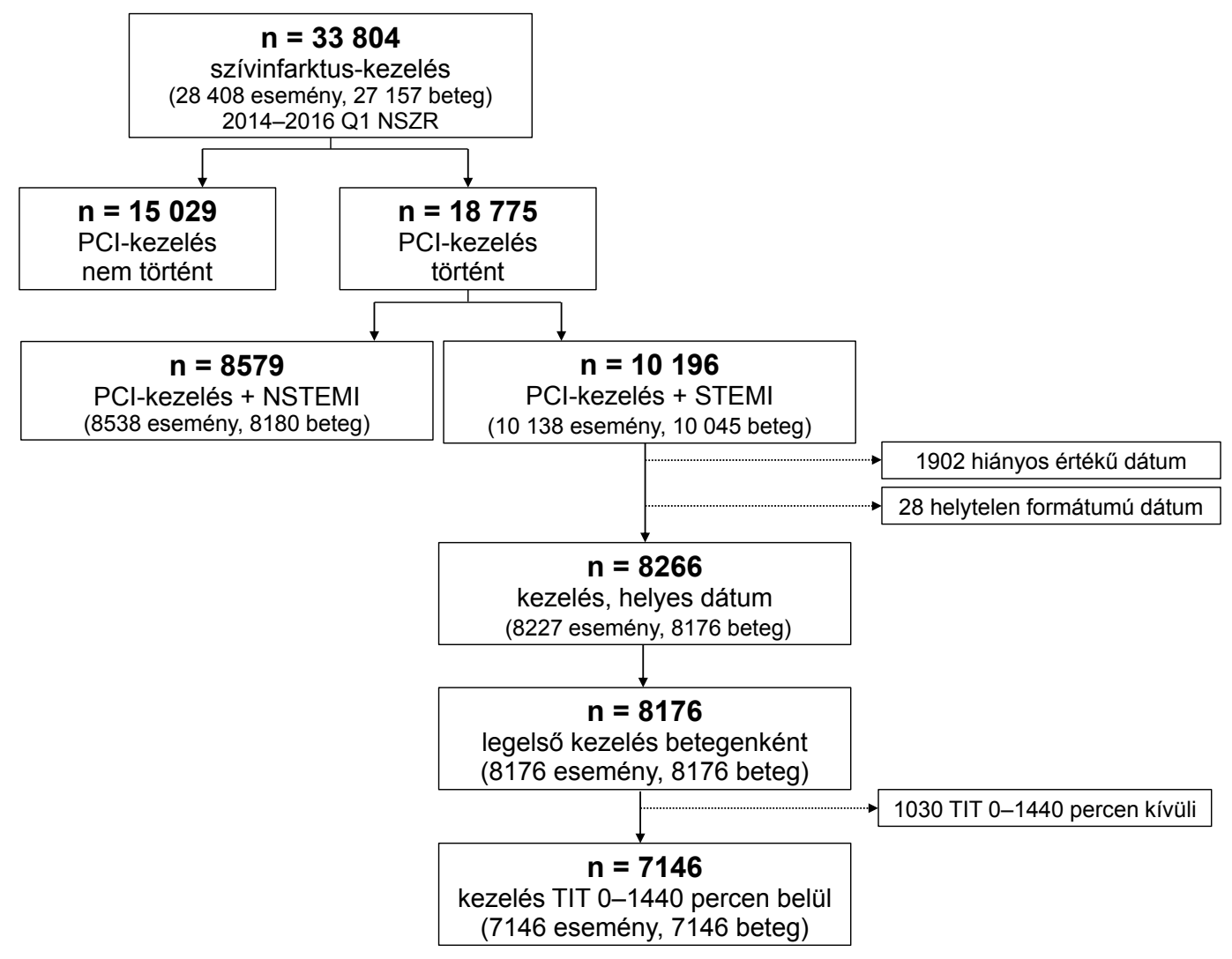

1. ábra

| A vizsgált betegcsoport kialakítása 
1. táblázat |A vizsgálatba bevont, illetve a vizsgálatból kizárt betegek klinikai adatainak összefoglalása

\begin{tabular}{|c|c|c|c|c|}
\hline & & Vizsgálatba bevont & Kihagyott & $\mathrm{p}$ \\
\hline $\mathrm{n}$ & & 7146 & 2899 & \\
\hline \multirow[t]{2}{*}{ Életkor } & Átlag (szórás) & $62,92(12,53)$ & $65,02(12,53)$ & $<0,01$ \\
\hline & $\mathrm{n}$ & 7146 & 2899 & \\
\hline \multirow[t]{2}{*}{ Nem } & Férfi & $4594(64,3 \%)$ & $1785(61,6 \%)$ & $<0,01$ \\
\hline & Nő & 2552 & 1114 & \\
\hline \multirow[t]{2}{*}{ Szívfrekvencia ${ }^{a}$} & Átlag (szórás) & $80,00(17,70)$ & $81,98(19,48)$ & $<0,01$ \\
\hline & $\mathrm{n}$ & 7079 & 2880 & \\
\hline \multirow[t]{2}{*}{ Szisztolés vérnyomás ${ }^{a}$} & Átlag (szórás) & $133,56(25,71)$ & $130,72(25,92)$ & $<0,01$ \\
\hline & $\mathrm{n}$ & 7070 & 2876 & \\
\hline \multirow[t]{2}{*}{ Diasztolés vérnyomás ${ }^{a}$} & Átlag (szórás) & $80,01(14,93)$ & $78,23(15,36)$ & $<0,01$ \\
\hline & $\mathrm{n}$ & 7068 & 2876 & \\
\hline \multirow[t]{4}{*}{ Szívinfarktus ${ }^{\mathrm{b}}$} & Igen & $1091(15,3 \%)$ & $546(18,8 \%)$ & $<0,01$ \\
\hline & $\mathrm{Nem}$ & 5778 & 2221 & \\
\hline & Nem ismert & 218 & 126 & \\
\hline & Nincs kitöltve & 59 & 6 & \\
\hline \multirow[t]{4}{*}{ Magas vérnyomás } & Igen & $5083(71,1 \%)$ & $2108(72,7 \%)$ & 0,05762 \\
\hline & Nem & 1858 & 698 & \\
\hline & Nem ismert & 149 & 87 & \\
\hline & Nincs kitöltve & 56 & 6 & \\
\hline \multirow[t]{4}{*}{ Periferiális érbetegség } & Igen & $590(8,3 \%)$ & $291(10,0 \%)$ & $<0,01$ \\
\hline & Nem & 5830 & 2306 & \\
\hline & Nem ismert & 657 & 285 & \\
\hline & Nincs kitöltve & 69 & 17 & \\
\hline \multirow[t]{4}{*}{ Stroke ${ }^{b}$} & Igen & $429(6,0 \%)$ & $199(6,9 \%)$ & 0,0966 \\
\hline & $\mathrm{Nem}$ & 6390 & 2547 & \\
\hline & Nem ismert & 285 & 145 & \\
\hline & Nincs kitöltve & 69 & 8 & \\
\hline \multirow[t]{4}{*}{ Diabetes mellitus } & Igen & $1710(23,9 \%)$ & $865(29,8 \%)$ & $<0,01$ \\
\hline & $\mathrm{Nem}$ & 5096 & 1895 & \\
\hline & Nem ismert & 270 & 130 & \\
\hline & Nincs kitöltve & 70 & 9 & \\
\hline \multirow[t]{4}{*}{$\mathrm{PCI}^{\mathrm{b}}$} & Igen & $1000(14,0 \%)$ & $473(16,3 \%)$ & $<0,01$ \\
\hline & $\mathrm{Nem}$ & 5577 & 2228 & \\
\hline & Nem ismert & 184 & 119 & \\
\hline & Nincs kitöltve & 385 & 79 & \\
\hline \multirow[t]{2}{*}{ Status ${ }^{c}$} & Él & $5964(83,5 \%)$ & $2195(75,7 \%)$ & $<0,01$ \\
\hline & Meghalt & 1182 & 704 & \\
\hline
\end{tabular}

${ }^{a}$ Felvételkor

${ }^{b}$ Kórelőzményben

‘Az l éves utánkövetés időpontjában

$\mathrm{p}=$ statisztikai különbség; $\mathrm{PCI}=$ percutan coronariaintervenció

vizsgálatból kizárt csoportban magasabb a nők aránya, idősebbek, a kórelőzményükben gyakrabban szerepelt szívinfarktus, stroke, illetve PCI. A társbetegségek (diabetes mellitus, hypertonia, perifériás érbetegség) előfordulása ugyancsak az úgynevezett kizárt csoportban volt gyakoribb. Mindezen tényezők alapján az elemzésből kizárt betegek klinikai állapota súlyosabb volt, ennek megfelelően ebben a csoportban az l éves utánkövetés idején alacsonyabb túlélési arányt találtunk $(75,7 \%$ versus $83,5 \%)$. 


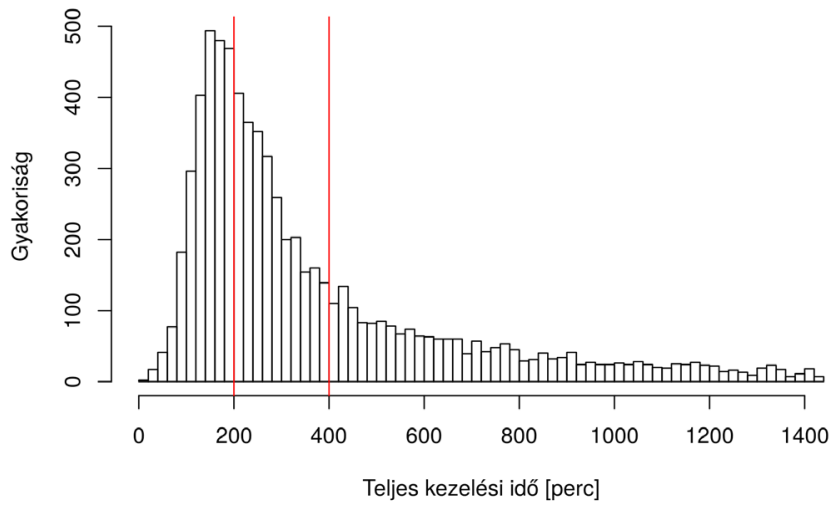

2. ábra |A kezelési idók

\section{Az utánkövetési idō átlaga}

A NEAK adatbázisából minden beteg állapotát (él versus meghalt) sikerült meghatározni. Az elemzés során a bármely okból bekövetkező halálesetet vettük figyelembe. Az átlagos utánkövetési idő $740 \pm 346$ nap volt.

\section{A teljes ischaemiás idó és annak összetevöi}

A TIT hisztogramszerú eloszlását a 2. ábra mutatja. A TIT mediánja 260 perc volt, q1: 172 perc, q3: 460 perc. A TIT leghosszabb komponense a panasz kezdetétől a kórházi felvételig eltelt idő (prehospitális idő), ennek mediánja mindhárom évben 205 perc körül volt. A TIT egyes összetevőinek alakulását - évenkénti bontásban - a 3. ábra foglalja össze.
2. táblázat $\mid$ A teljes ischaemiás idő hossza alapján kialakított betegcsoportok és a halálozás

\begin{tabular}{lccc}
\hline & 0-199 perc & 200-399 perc & $\geq 400$ perc \\
\hline A betegek száma & 2381 & 2618 & 2147 \\
Él & 2033 & 2207 & 1724 \\
Meghalt & 348 & 411 & 423 \\
Halálozás (\%) & 14,62 & 15,7 & 19,7 \\
\hline
\end{tabular}

\section{A betegek túlélése a teljes ischaemiás ido" függvényében}

A teljes utánkövetési idő alatt - bármely - okból bekövetkező halálozást az egyes betegcsoportokban a 2. táblázat tartalmazza. A teljes ischaemiás idő hosszának növekedése esetén a halálozási arányt is magasabbnak találtuk. Amennyiben a TIT 400 percnél rövidebb volt, akkor a 30 napos, illetve 1 éves halálozás $7,5 \%$, illetve $12,2 \%$ volt, az ennél hosszabb TIT esetén 9,2, illetve 19,7\%-os halálozást találtunk. A 30 napos, az l éven belüli és az 1 éven túli halálozás szignifikánsan magasabb volt azon betegeknél, akiknél a TIT 400 perc vagy annál hosszabb volt azon betegekhez képest, akiknél a TIT 400 percnél rövidebb volt $\left(\mathrm{khi}^{2}=5,228, \mathrm{p}=0,0222\right.$; $\left.\mathrm{khi}^{2}=21,891, \mathrm{p}<0,01 ; \mathrm{khi}^{2}=6,9951, \mathrm{p}=0,0081\right) . \mathrm{A}$ csoportok Kaplan-Meier-féle túlélési görbéjét a 4. ábra mutatja. A 200 percnél rövidebb és a 200 és 400 perc közötti csoportba tartozó betegek túlélési görbéje között nem találtunk különbséget, viszont a 400 perc vagy annál hosszabb TIT esetén a prognózis lényegesen roszszabb.

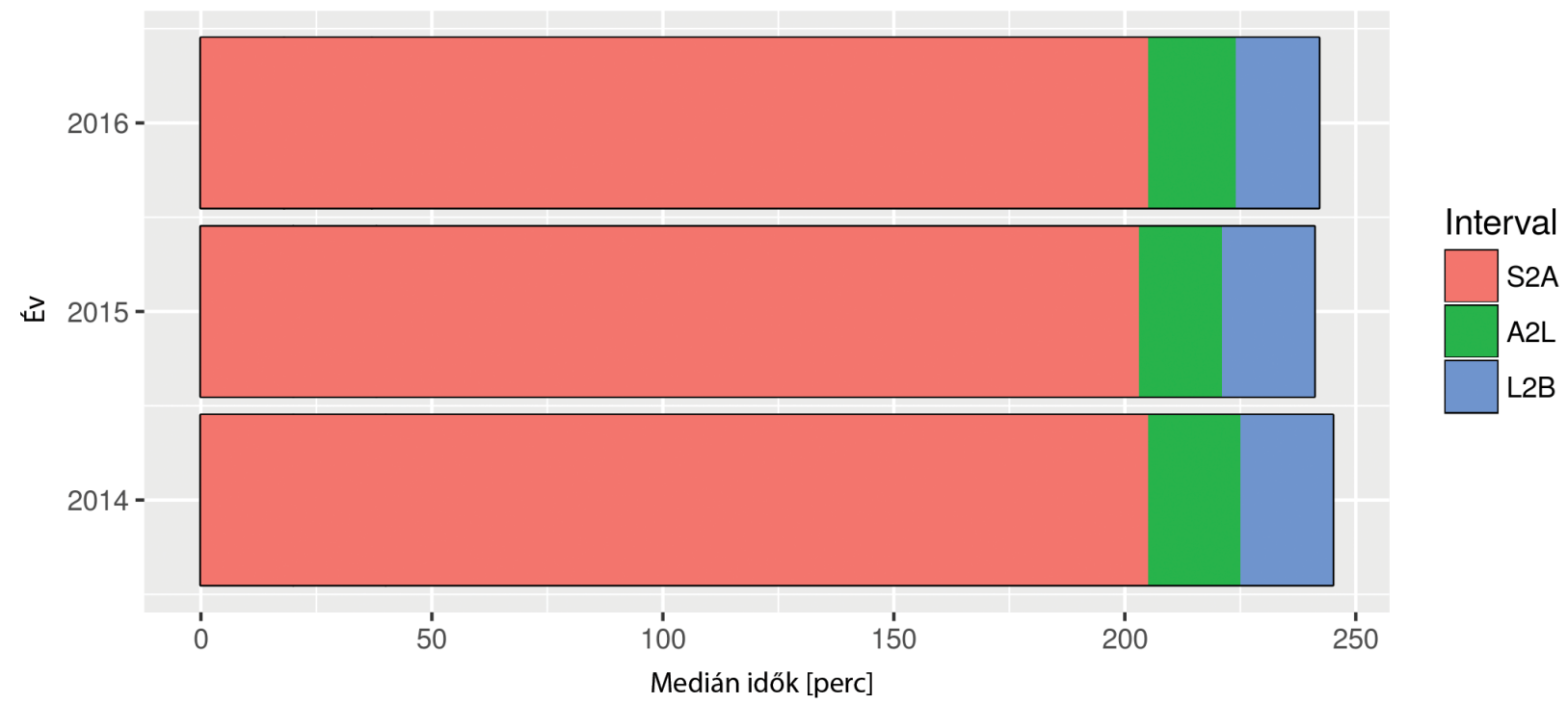

\begin{tabular}{l|l} 
3. ábra & $\begin{array}{l}\text { A teljes ischaemiás idő (TIT) összetevőinek mediánja évenkénti bontásban } \\
\text { S2A = a panasz kezdetétől a kórházi felvételig eltelt idő; A2L = a kórházi felvételtől a szívkatéteres laboratóriumba érkezésig eltelt idő; L2B = a szív- } \\
\text { katéteres laboratóriumba érkezéstől a ballon felfújásáig eltelt idő }\end{array}$
\end{tabular} 


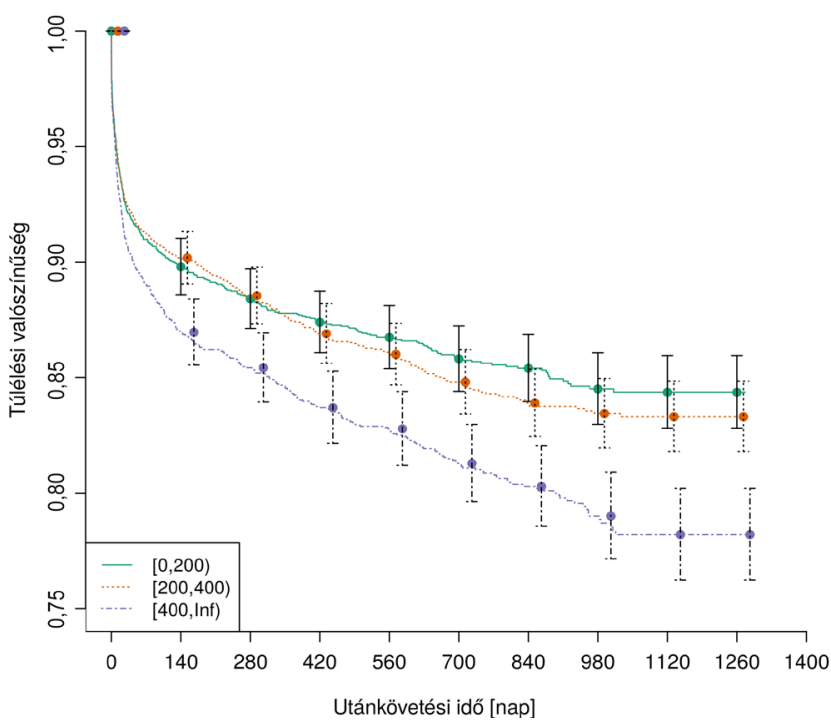

4. ábra $\mid$ A teljes ischaemiás idő hossza alapján kialakított betegcsoportok és az egy éves halálozás

\section{A túlélést befolyásoló tényezốk egyváltozós elemzése}

A teljes utánkövetési idő alatti halálozás tekintetében egyváltozós analízis során - 16 tényező prognosztikai szempontból jelentősnek, statisztikai szempontból szignifikánsnak bizonyult. Az ismert prognosztikai tényezőkön kívül a teljes ischaemiás idő is - jelentősen - befolyásolta a túlélést. A részleteket a 3. táblázat tartalmazza.

3. táblázat |A túlélést befolyásoló tényezők egyváltozós elemzése

\begin{tabular}{lcc}
\hline Jellemzők (referencia) & HR & p \\
\hline Nem (ref.: férfi) & $1,566<0,01$ \\
Életkor & $1,068<0,01$ \\
Kórelőzményben infarktus (ref.: igen) & $0,623<0,01$ \\
Kórelőzményben magas vérnyomás (ref.: igen) & $0,607<0,01$ \\
Kórelőzményben periferiális érbetegség (ref.: igen) & $0,390<0,01$ \\
Kórelőzményben stroke (ref.: igen) & $0,375<0,01$ \\
Kórelőzményben diabetes (ref.: igen) & $0,612<0,01$ \\
Kórelőzményben PCI (ref.: igen) & $0,692<0,01$ \\
Szívfrekvencia (felvételkor) & $1,016<0,01$ \\
Szisztolés vérnyomás (felvételkor) & $0,979<0,01$ \\
Diasztolés vérnyomás (felvételkor) & $0,970<0,01$ \\
Szérumkreatinin (ref: abnormális) & $0,322<0,01$ \\
A behatolás formája (radialis) & $0,355<0,01$ \\
A koronarográfia eredménye (fötörzs + 3 ér) & $4,549<0,01$ \\
Shock kezelés alatt (ref.: igen) & $0,092<0,01$ \\
Teljes ischaemiás idő (400 perc s) & $1,379<0,01$ \\
\hline
\end{tabular}

$\mathrm{HR}=($ hazard ratio $)$ kockázati arány; $\mathrm{p}=$ statisztikai különbség

\section{A túlélést befolyásoló tényezök többváltozós, Cox-regressziós vizsgálata}

Az egyváltozós elemzéssel szignifikánsnak bizonyult tényezők jelentőségét többváltozós elemzéssel is vizsgáltuk az utánkövetés különböző időpontjaiban (<30 nap, 30-364 nap, $\geq 365$ nap). A diabetes a rövid távú ( $<30$ nap) halálozást befolyásolta. A rövid és középtávú halálozást a kóros kreatininérték, a súlyos koszorúérstatus és a behatolás formája befolyásolta. A közép- és a hosszú távú túlélés szempontjából jelentôs volt a kezelés során elvégzett PCI. A teljes ischaemiás idő és a kórelőzményben szereplő infarktus csak a hosszú távú prognózis tekintetében volt jelentős. A 200 percnél rövidebb TIThez viszonyítva az ennél hosszabb idő $45 \%$-kal növelte a halálozás relatív rizikóját (HR: 1,457, 95\% CI 1,029$2,062, \mathrm{p}=0,034)$. Az életkor, a kórelőzményben szereplő stroke, a perifériás érbetegség, a felvételkor mért szisztolés vérnyomás és szívfrekvencia, valamint a kezelés alatt kialakult shock mindhárom vizsgálati idöszakban szignifikánsan befolyásolta a túlélést. A részleteket a 4., az 5. és a 6. táblázat tartalmazza.

4. táblázat |A túlélést befolyásoló tényezők többváltozós analízise, amelynél a halálozási idő kevesebb, mint 30 nap

\begin{tabular}{lcccc}
\hline Jellemző́k (referencia) & \multicolumn{4}{c}{ Halálozási idő <30 nap } \\
\cline { 2 - 5 } & HR & \multicolumn{2}{c}{$95 \%$ CI } & $\mathrm{p}$ \\
\hline Nem (ref.: férfi) & 0,791 & 0,662 & 0,946 & 0,010 \\
Életkor & 1,047 & 1,038 & 1,055 & $<0,01$ \\
Infarktus $^{\mathrm{a}, \mathrm{b}}$ & 0,991 & 0,731 & 1,345 & 0,956 \\
Magas vérnyomás $^{\mathrm{a}, \mathrm{b}}$ & 0,948 & 0,748 & 1,203 & 0,663 \\
Periferiális érbetegséga, $^{\mathrm{a}, \mathrm{b}}$ & 0,744 & 0,578 & 0,956 & 0,021 \\
Stroke $^{\mathrm{a}, \mathrm{b}}$ & 0,613 & 0,473 & 0,796 & $<0,01$ \\
Diabetes $^{\mathrm{a}, \mathrm{b}}$ & 0,822 & 0,676 & 0,999 & 0,048 \\
PCI $^{\mathrm{a}, \mathrm{b}}$ & 1,324 & 0,929 & 1,888 & 0,121 \\
Szívfrekvencia $^{\mathrm{c}}$ & 1,017 & 1,013 & 1,021 & $<0,01$ \\
Szisztolés vérnyomás $^{\mathrm{c}}$ & 0,986 & 0,981 & 0,992 & $<0,01$ \\
Diasztolés vérnyomás $^{\mathrm{c}}$ & 0,997 & 0,988 & 1,005 & 0,413 \\
Szérumkreatinin $^{\mathrm{d}}$ & 0,561 & 0,461 & 0,683 & $<0,01$ \\
A behatolás formája $^{\mathrm{c}}$ & 0,527 & 0,374 & 0,742 & $<0,01$ \\
Koronarográfia $^{\mathrm{f}}$ & 2,666 & 1,593 & 4,462 & $<0,01$ \\
Shock kezelés alatt $^{\mathrm{b}}$ & 0,237 & 0,184 & 0,306 & $<0,01$ \\
Teljes ischaemiás idô $^{\mathrm{g}}$ & 1,027 & 0,830 & 1,269 & 0,809 \\
\hline
\end{tabular}

aKórelőzményben

${ }^{b}$ Referencia: igen

'Felvételkor

${ }^{\mathrm{d}}$ Referencia: abnormális

${ }^{\mathrm{c}}$ Radialis

fEredmény, fötörzs + 3 ér versus egyéb

$\mathrm{g}(400$ perc $\leq)$

$\mathrm{CI}=$ konfidenciaintervallum; $\mathrm{HR}=($ hazard ratio $)$ kockázati arány; $\mathrm{p}$ = statisztikai különbség; $\mathrm{PCI}=$ percutan coronariaintervenció 
A túlélést befolyásoló tényezők többváltozós analízise, amelynél a halálozási idő 30 és 364 nap közé esik

\begin{tabular}{|c|c|c|c|c|}
\hline \multirow{3}{*}{$\begin{array}{l}\text { Jellemzők (referencia) } \\
\text { Nem (ref.: férfi) }\end{array}$} & \multicolumn{4}{|c|}{ Halálozási idő 30-364 nap } \\
\hline & \multirow{2}{*}{$\frac{\mathrm{HR}}{1,016}$} & \multicolumn{2}{|c|}{$95 \% \mathrm{CI}$} & \multirow{2}{*}{$\frac{\mathrm{p}}{0,888}$} \\
\hline & & 0,817 & 1,263 & \\
\hline Életkor & 1,061 & 1,051 & 1,072 & $<0,01$ \\
\hline Infarktus ${ }^{\mathrm{a}, \mathrm{b}}$ & 0,975 & 0,682 & 1,393 & 0,889 \\
\hline Magas vérnyomás ${ }^{\mathrm{a}, \mathrm{b}}$ & 0,936 & 0,706 & 1,242 & 0,647 \\
\hline Periferiális érbetegséga, b & 0,589 & 0,442 & 0,786 & $<0,01$ \\
\hline Stroke ${ }^{\mathrm{a}, \mathrm{b}}$ & 0,648 & 0,468 & 0,898 & $<0,01$ \\
\hline Diabetes $^{\mathrm{a}, \mathrm{b}}$ & 0,876 & 0,695 & 1,103 & 0,261 \\
\hline $\mathrm{PCI}^{\mathrm{a}, \mathrm{b}}$ & 0,734 & 0,511 & 1,056 & 0,096 \\
\hline Szívfrekvencia ${ }^{c}$ & 1,016 & 1,011 & 1,022 & $<0,01$ \\
\hline Szisztolés vérnyomás ${ }^{c}$ & 0,993 & 0,987 & 0,999 & 0,030 \\
\hline Diasztolés vérnyomás ${ }^{c}$ & 1,000 & 0,989 & 1,011 & 0,973 \\
\hline Szérumkreatinin $^{\mathrm{d}}$ & 0,676 & 0,534 & 0,855 & $<0,01$ \\
\hline A behatolás formája ${ }^{\mathrm{c}}$ & 0,535 & 0,331 & 0,866 & $<0,01$ \\
\hline Koronarográfia $^{\mathrm{f}}$ & 2,169 & 1,055 & 4,459 & 0,035 \\
\hline Shock kezelés alatt ${ }^{\mathrm{b}}$ & 0,484 & 0,307 & 0,764 & $<0,01$ \\
\hline Teljes ischaemiás időg & 1,169 & 0,905 & 1,510 & 0,233 \\
\hline
\end{tabular}

${ }^{a}$ Kórelőzményben

${ }^{b}$ Referencia: igen

'Felvételkor

'Referencia: abnormális

'Radialis

${ }^{\mathrm{f} E}$ Eredmény, fötörzs +3 ér versus egyéb

$\mathrm{g}(400$ perc $\leq)$

$\mathrm{CI}=$ konfidenciaintervallum; $\mathrm{HR}=$ (hazard ratio) kockázati arány; $\mathrm{p}$ = statisztikai különbség; PCI = percutan coronariaintervenció

\section{Megbeszélés}

Vizsgálatunkban a teljes ischaemiás idő prognosztikus jelentőségét vizsgáltuk ST-elevációval járó szívinfarktust elszenvedett betegekben. A TIT számos részidő összege, ennek első komponense az ér thromboticus elzáródása és a panasz fellépése közötti idő, amelyet a beteg döntési ideje követ. A panasz megfelelő értékelésekor és az ebből következő továbblépéskor fontos, hogy a beteg megfelelǒen értékelje a tünetet, illetve a panaszt. A TIT harmadik összetevője az orvosi segítség kérése, míg a negyedik időintervallum, amíg a beteg eljut az adekvát ellátási helyre, ST-elevációval járó infarktus esetén a szívkatéteres laboratóriumba, ahol megtörténik a revascularisatio $[7,8]$. Praktikus okokból a TIT-et a panasz fellépésétől az ér megnyitásáig eltelt idő alapján határozzák meg. Vizsgálatunkban a TIT mediánja 260 perc. A koreai infarktusregiszter adatait feldolgozó közleményben [9] a TIT igen hasonló az általunk észlelthez, és több év adatait elemezve csak minimális csökkenést észleltek. Danchin [10] hasonló, bár valamivel rövidebb TIT-ról
6. táblázat |A túlélést befolyásoló tényezők többváltozós analízise, amelynél a halálozási idő több, mint 364 nap

\begin{tabular}{|c|c|c|c|c|}
\hline \multirow{3}{*}{$\begin{array}{l}\text { Jellemzők (referencia) } \\
\text { Nem (ref.: férfi) }\end{array}$} & \multicolumn{4}{|c|}{ Halálozási idő $\geq 365$ nap } \\
\hline & \multirow{2}{*}{$\begin{array}{c}\text { HR } \\
1,094\end{array}$} & \multicolumn{2}{|c|}{$95 \% \mathrm{CI}$} & \multirow{2}{*}{$\begin{array}{c}\mathrm{p} \\
0,539\end{array}$} \\
\hline & & 0,821 & 1,457 & \\
\hline Életkor & 1,058 & 1,045 & 1,072 & $<0,01$ \\
\hline Infarktus ${ }^{\mathrm{a}, \mathrm{b}}$ & 0,671 & 0,431 & 1,046 & 0,078 \\
\hline Magas vérnyomás ${ }^{\mathrm{a}, \mathrm{b}}$ & 0,925 & 0,641 & 1,333 & 0,675 \\
\hline Periferiális érbetegséga, b & 0,550 & 0,376 & 0,805 & $<0,01$ \\
\hline Stroke $\mathrm{e}^{\mathrm{a}, \mathrm{b}}$ & 0,684 & 0,441 & 1,060 & 0,089 \\
\hline Diabetes $^{\mathrm{a}, \mathrm{b}}$ & 0,921 & 0,679 & 1,249 & 0,597 \\
\hline $\mathrm{PCI}^{\mathrm{a}, \mathrm{b}}$ & 0,633 & 0,400 & 1,002 & 0,051 \\
\hline Szívfrekvencia ${ }^{c}$ & 1,012 & 1,004 & 1,019 & $<0,01$ \\
\hline Szisztolés vérnyomás ${ }^{c}$ & 0,988 & 0,979 & 0,996 & $<0,01$ \\
\hline Diasztolés vérnyomás ${ }^{c}$ & 1,012 & 0,997 & 1,026 & 0,125 \\
\hline Szérumkreatinin $^{\mathrm{d}}$ & 0,767 & 0,558 & 1,054 & 0,102 \\
\hline A behatolás formája ${ }^{\mathrm{e}}$ & 1,494 & 0,551 & 4,053 & 0,431 \\
\hline Koronarográfia $^{\mathrm{f}}$ & 2,212 & 0,800 & 6,113 & 0,126 \\
\hline Shock kezelés alatt ${ }^{\mathrm{b}}$ & 0,470 & 0,256 & 0,865 & 0,015 \\
\hline Teljes ischaemiás ido"g & 1,457 & 1,029 & 2,062 & 0,034 \\
\hline
\end{tabular}

aKórelőzményben

${ }^{b}$ Referencia: igen

'Felvételkor

${ }^{\mathrm{d}}$ Referencia: abnormális

'Radialis

${ }^{\mathrm{f}}$ Eredmény, fötörzs +3 ér versus egyéb

$\mathrm{g}(400$ perc $\leq)$

$\mathrm{CI}=$ konfidenciaintervallum; $\mathrm{HR}=$ (hazard ratio) kockázati arány; $\mathrm{p}=$ statisztikai különbség; PCI = percutan coronariaintervenció

számolt be. A FINESSE-vizsgálatban a TIT lényegesen rövidebbnek bizonyult az általunk észlelt értéknél [11]. Adataink szerint a TIT leghosszabb - ezért a legfontosabb - összetevője a prehospitális késés, amely a vizsgált években alig változott. Vizsgálatunkban a 400 perces vagy annál hosszabb TIT szignifikáns mértékben növelte az egyéves halálozás kockázatát. Vizsgálatunkkal megegyező adatot közöltek a svéd infarktusregiszter adatait feldolgozó tanulmányban [12]. Shiomi [6] a 3 éves utánkövetés során azt találta, hogy a 3 órát meghaladó TIT esetén szignifikánsan gyakoribb volt a szívelégtelenség és a halálozás. De Luca [3] közlése szerint az l éves halálozás relatív kockázata minden 30 perces késés esetén 7,5\%-kal nő. Cannon és mtsai közlésében az ajtó-ballon idő jelentősebbnek bizonyult, mint a TIT [13], bár ebben a vizsgálatban meglehetôsen hosszú volt az ajtó-ballon idő: a medián érték 1 óra 56 perc. Solhpour és mtsai [14] a szív-MR-rel vizsgálták az infarktus nagyságának összefüggését a TIT-tel. Vizsgálatukban az ischaemiás idő hossza szoros összefüggést mutatott az elhalt szívizom tömegével és az indexeseményt követő halálozás- 
sal. Az Accelerator-2-vizsgálatban Jollis és mtsai [15] a STEMI-betegek ellátásának regionális megszervezésével csökkentették az ischaemiás időt, és ezzel párhuzamosan jelentősen csökkent a betegek halálozása.

\section{Következtetések}

1. Az NSZR adatai szerint Magyarországon a panasz kezdetétől az ér megnyitásáig eltelt idő (TIT) kedvezőtlenül hosszú, ezért a kezelés eredményessége elmarad az időben végzett katéteres érmegnyitás hatékonyságától.

2. A teljes ischaemiás idő közel $80 \%$-a prehospitális késlekedés következménye.

3. Az optimálisnál hosszabb TIT miatt a megmentett szívizom tömege - nagy valószínúséggel - kisebb a lehetségesnél.

4. Az NSZR nagy betegszámú adatbázisát többfaktoros módszerrel elemezve azt találtuk, hogy a TIT önálló prognosztikai jelentóséggel bír a STEMI-betegek hosszú távú (egyéves, illetve ennél hosszabb időszak) halálozásának tekintetében.

5. A teljes ischaemiás idő csökkentése a hosszú távú prognózis javulását eredményezheti.

6. A prehospitális idő (a betegek késlekedése, az első egészségügyi ellátó késlekedése) további elemzése szükséges ennek csökkentése és az ellátás optimalizálása érdekében.

Vizsgálatunk értéke, hogy nagy számú, konszekutív beteg adatait elemeztük. Rámutattunk arra, hogy hazánkban jelenleg a TIT hosszú, az érmegnyitásra nem optimális időben kerül sor. Vizsgálatunk limitációja, hogy csak a túléléssel kapcsolatos adatokkal rendelkezünk, a szívelégtelenség késői előfordulásának gyakoriságát nem ismerjük.

Anyagi támogatás: A kutatás anyagi támogatásban nem részesült.

Szerzői munkamegosztás: J. A.: A kutatási cél meghatározása, az adatok elemzése, a közlemény összeállítás. E. G.: A „Kiemelt halálozási kockázatú betegségek megelőzésének és ellátásának Big Data elemzése" program vezetője. P. F. P.: Az adatok statisztikai elemzése. F. T.: A közlemény megírásában való részvétel, az irodalmi adatok összegyüjtése és értelmezése. U. I.: Az adatgyưjtésben és az adatok értékelésében való részvétel, irodalomkutatás. A. P.: A kutatási terv és a kézirat végleges formájának kialakításában való részvétel. O.P.: A kutatási terv és a kézirat végleges formájának kialakításában való részvétel. A cikk végleges változatát valamennyi szerző átolvasta és jóváhagyta.

Érdekeltségek: A szerzőknek nincsenek érdekeltségeik.

\section{Irodalom}

[1] Reimer KA, Lowe JE, Rasmussen MM, et al. The wave front phenomenon of ischemic cell death. 1. Myocardial infarct size vs duration of coronary occlusion in dogs. Circulation 1977; 56 : 786-794.

[2] Boersma E, Maas AC, Deckers JW, et al. Early thrombolytic treatment in acute myocardial infarction: reappraisal of the golden hour. Lancet 1996; 348: 771-775.

[3] De Luca G, Suryapranata H, Ottervanger JP, et al. Time delay to treatment and mortality in primary angioplasty for acute myocardial infarction: every minute of delay counts. Circulation 2004; 109: 1223-1225.

[4] Gersh BJ, Stone GW, White HD, et al. Pharmacological facilitation of primary percutaneous coronary intervention for acute myocardial infarction: is the slope of the curve the shape of the future? JAMA 2005; 293: 979-986.

[5] Jánosi A, Ofner P, Merkely B, et al. Short and long term prognosis of patients with myocardial infarction. Hungarian Myocardial Infarction Registry. [Szívinfarktus miatt kezelt betegek rövid és hosszú távú prognózisa. Magyar Szívinfarktus Regiszter.] Orv Hetil. 2013; 154: 1297-1302.

[6] Shiomi H, Nakagawa Y, Morimoto T, et al. Association of onset to balloon and door to balloon time with long term clinical outcome in patients with ST elevation acute myocardial infarction having primary percutaneous coronary intervention: observational study. BMJ 2012; 344: e3257.

[7] Fischell TA, Fischell DR, Fischell RE, et al. Potential of an intracardiac electrogram for the rapid detection of coronary artery occlusion. Cardiovasc Revasc Med. 2005; 6: 14-20.

[8] Denktas AE, Anderson HV, McCarthy J, et al. Total ischemic time: the correct focus of attention for optimal ST-segment elevation myocardial infarction care. JACC Cardiovasc Interv. 2011; 4: 599-604.

[9] Kim HK, Jeong MH, Ahn Y, et al. Relationship between time to treatment and mortality among patients undergoing primary percutaneous coronary intervention according to Korea Acute Myocardial Infarction Registry. J Cardiol. 2017; 69: 377-382.

[10] Danchin N, Blanchard D, Steg PG, et al. Impact of prehospital thrombolysis for acute myocardial infarction on 1-year outcome: results from the French Nationwide USIC 2000 Registry. Circulation 2004; 110: 1909-1915.

[11] Ellis SG, Tendera M, de Belder MA, et al. Facilitated PCI in patients with ST-elevation myocardial infarction. N Engl J Med. 2008; 358: 2205-2217.

[12] Koul S, Andell P, Martinsson A, et al. Delay from first medical contact to primary PCI and all-cause mortality: a nationwide study of patients with ST-elevation myocardial infarction. J Am Heart Assoc. 2014; 3: e000486.

[13] Cannon CP, Gibson CM, Lambrew CT, et al. Relationship of symptom-onset-to-balloon time and door-to-balloon time with mortality in patients undergoing angioplasty for acute myocardial infarction. JAMA 2000; 283: 2941-2947.

[14] Solhpour A, Chang KW, Arain SA, et al. Ischemic time is a better predictor than door-to-balloon time for mortality and infarct size in ST-elevation myocardial infarction. Catheter Cardiovasc Interv. 2016; 87: 1194-1200.

[15] Jollis JG, Al-Khalidi HR, Roettig ML, et al. Impact of regionalization of ST-segment-elevation myocardial infarction care on treatment times and outcomes for emergency medical services transported patients presenting to hospitals with percutaneous coronary intervention: Mission: Lifeline Accelerator-2. Circulation 2018; 137: 376-387.

(Jánosi András dr., Budapest, Haller u 29., 1096 e-mail: janosi.andras@kardio.hu) 